\title{
ОРГАНИЗАЦИЯ И СТАНОВЛЕНИЕ ОРЕНБУРГСКОГО ИНСТИТУТА НАРОДНОГО ОБРАЗОВАНИЯ В 1919-1921 гГ.
}

\author{
(c) 2020 С.В. Любичанковский
}

Самарский федеральный исследовательский центр РАН, Оренбургский государственный педагогический университет

Статья поступила в редакцию 03.08.2020

\begin{abstract}
В статье на основании архивных документов, извлеченных из фондов Государственного архива Оренбургской области, реконструирован процесс организации в Оренбурге нового высшего учебного заведения педагогического профиля - Института народного образования. Рассмотрен первый этап его развития (1919-1921 гг.), связанный со становлением этого учебного заведения, созданием его материальной базы, формированием кадрового состава и структуры учебного процесса.

Ключевые слова: образование, Институт народного образования, педагогические вузы, советская Россия, Оренбургский край.
\end{abstract}

DOI: $10.37313 / 2658-4816-2020-2-4-29-35$

C дореволюционных времен Россия всегда уделяла большое внимание развитию системы образования, особенно на своих поликультурных окраинах, справедливо полагая этот вопрос важной частью интеграции населения в единое социокультурное пространство. Поэтому в Оренбургском крае сложились крепкие традиции просветительской работы среди населения ${ }^{1}$.

В системе образования России после октября 1917 года начали происходить фундаментальные изменения. В октябре пост народного комиссара по просвещению занял Анатолий Васильевич Луначарский. Он сыграл важную роль в привлечении старой интеллигенции на сторону большевиков. Педагогические круги ждали от «невежественных узурпаторов» ликвидации наук и искусств, однако в ноябре этого года народный комиссариат по просвещению опубликовал обращение «О народном просвещении», в котором разъяснялись принципы

Любичанковский Сергей Валентинович, доктор исторических наук, профессор, ведущий научный сотрудник Самарского федерального исследовательского центра РАН, заведующий кафедрой истории России Оренбургского государственного педагогического университета.

E-mail:svlubich@yandex.ru новой учебной деятельности советского государства. Затем, в октябре 1918 года, последовали «Декларация о единой трудовой школе» и «Положение о единой трудовой школе РСФСР», в соответствии с которыми во всех школах первой и второй ступеней вводилось бесплатное, совместное и светское образование; серьезное значение придавали также физическому, трудовому и эстетическому воспитанию.

По свидетельству архивных источников, в Оренбурге организовывать такие школы стали только осенью 1919 года, когда на территории губернии закончилась гражданская война. Под руководством местного отдела народного образования по губернии был разослан декрет ВЦИК «Положение о единой трудовой школе РСФСР», прошли собрания и съезды учителей. Старые разноведомственные учебные заведения заменили школы первой и второй ступеней. По всей губернии (в казачьих станицах, крестьянских селах, казахских аулах и т.д.) открывались новые школы. В марте 1920 года губоно в отчете II губернскому съезду Советов отмечал, что «общее количество школ значительно увеличилось». Осенью в Оренбургской губернии их уже насчитывалось 1476 
(150,5 тыс. учащихся). Одним из следствий этого в целом очень позитивного процесса стала нехватка учителей. Практикуемые двухмесячные курсы, естественно, не смогли изменить ситуацию. В органы народного образования из районов массово поступали заявки на учителей во вновь открываемые школы, причем на учителей с качественным педагогическим образованием.

В 1919 году при Оренбургском губоно была создана специальная секция по подготовке работников просвещения, а также открывались краткосрочные учительские курсы, действующие в разных местах губернии (Оренбург, Орск и т.д.). В 1919-1920 годы таким образом было подготовлено около тысячи учителей для школ первой ступени, однако по-прежнему не хватало учительских кадров для школ второй ступени.

9 июля 1919 года Народный комиссариат просвещения РСФСР принял постановление о преобразовании ряда учительских семинарий $^{2}$ и институтов в институты народного образования³. Они стали первыми специальными высшими учебными заведениями по подготовке квалифицированных кадров учителей для советских школ. В этом же постановлении упоминается о том, что необходимо принять меры к тому, чтобы с начала наступающего учебного года были организованы первый и второй курс, «дабы не произошло перерыва в выпуске новых школьных работников». Все имущество преобразуемых учебных семинарий, а также кредиты переходили по принадлежности институтам народного образования ${ }^{4}$.

В соответствии с постановлением Наркомпроса от 9 июля 1919 года губернский отдел народного образования организовал инициативную группу по созданию в Оренбурге на базе учительского института нового высшего учебного заведения - Института народного образования. В нее вошли работники отдела и наиболее опытные преподаватели города. 30 сентября коллегия губоно поручила организацию института В.Я. Струминскому, В.П. Виноградову и А.Ф. Парфяновичу. Ими и был разработан проект ор- ганизации в городе Оренбурге Института Народного Образования (зарегистрирован губоно 9 июля 1919 г. под номером 9316). Согласно проекту, проектируемый институт должен был обеспечить всестороннее развитие личности обучающегося и при этом учитывать, особенно в первое время, разный уровень подготовки поступающих студентов 5 .

Председателем правления института был избран Василий Яковлевич Струминский - известный не только в губернии, но и в России специалист в области педагогики, впоследствии - доктор педагогических наук, профессор, член-корреспондент Академии педагогических наук СССР. До этого с 1915 года В.Я. Струминский преподавал в Оренбургском учительском институте. В Институте он проработал ректором до 1926 г., после был переведен в Казанский педагогический институт. Семь лет, осуществляя ректорские обязанности, он вел большую работу с учителями и деятелями народного образования - читал лекции о принципах построения и путях становления и развития советской школы. В 19221923 гг. в Оренбурге вышли подготовленные В.Я. Струминским три выпуска «Настольной книги для работников трудовой школы», в которых анализировались новые школьные программы и давались практические рекомендации руководителям школ и учителям. Позже, в 1951 году, за заслуги в области народного образования Василий Яковлевич был награжден орденом Ленина.

Помимо В.Я. Струминского в состав руководства Института вошли следующие специалисты: В.П. Виноградов был избран секретарем Совета Института, Н.А. Лебедев - заведующим основным курсом и словесноисторическим отделением, И.М. Чубинский - заведующим физико-математического и биологического факультета, М.И. Вишковский - заведующим отделением трудовых процессов ${ }^{6}$. Как можно увидеть из этого перечня, институт явно испытывал кадровый голод, что проявилось как в небольшом количестве структурных подразделений, так и 
в допустимости совмещения одним человеком постов руководителей сразу двух таковых подразделений.

Коллегия губоно утвердила состав преподавателей института, в него вошли наиболее квалифицированные преподаватели бывшего учительского института, имевшие, как правило, университетское образование и большой опыт педагогической работы. Среди них К.А. Токмаков, А.П. Райский, Л.М. Краснов, Н.А. Лебедев и другие, а всего 24 педагога.

Городские власти оставили за Институтом народного образования здание бывшего учительского института, расположенное в городе Оренбурге по Кривцовской улице (современная ул. Пионерская).

В начале октября 1919 года был объявлен и проведен набор студентов. Заявления о приеме в Институт народного образования подавали выпускники учительского института, гимназий, реального училища, учителя школ и т.д. Среди первых студентов было всего несколько коммунистов и комсомольцев. 19 октября в Оренбургском институте народного образования для 150 человек начались учебные занятия на основном отделении (заведующий Н.А. Лебедев), физико-математическом (заведующий И.М. Чубинский), биологическом, словесно-историческом и отделении трудовых процессов (заведующий М.И. Витковский). В дальнейшем в институте были организованы еще дошкольное и внешкольное отделения. Обучение продолжалось 4 года. Студенты имели право на получение стипендии. Социальная помощь студентам выделяется из следующего расчета: полное пищевое довольствие - 1000 рублей, общежитие - 300, учебные пособия - 150, белье, одежда, обувь - 325, прачечная и баня - 125 , медицинская помощь - 250 рублей ${ }^{7}$

Учебный процесс только организованного института чуть не был сорван мобилизацией в Красную армию, которая грозила забрать большую часть студентов. В объявлении от 13 декабря 1919 года № 7683 указывалось, что руководству необходимо оставить только крайне незаменимых работников учреждений. Остальные подлежали мобилизации. В ответе совета Института народного образования говорилось о том, что из 150 слушателей Института призыву подлежит половина, и следовала просьба об отсрочке до окончания учебного года. В.Я. Струминский отмечал, что Институт народного образования в Оренбурге был организован всего 1,5 месяца тому назад и начал свою работу при обстоятельствах очень неблагоприятных: за истекшие 1,5 месяца ему пришлось пережить два переселения в 24-часовой срок и не менее трех раз ему грозило закрытие в связи со свирепствующей эпидемией. Несмотря на это институт все же наладил свою внутреннюю жизнь, и вот уже третью неделю занятия идут в нормальном порядке. Далее была просьба об отсрочке призыва ${ }^{8}$.

Ректор вуза своего добился: согласно соглашению Советского Всероссийского Главного Штаба с наркоматом просвещения всем студентам, командированным предприятиями, была предоставлена отсрочка. Чуть позже административно-мобилизационный отдел уездвоенкомата официально сообщил в Институт, что состоящие слушателями института мобилизации не подлежат ${ }^{9}$.

С 1 октября 1920 года в Институте был открыт внешкольный отдел и пятимесячные курсы для подготовки внешкольных работников, в том числе и инструкторов, в области библиотечной, клубной работы, работников народных домов, школ взрослых, музейной и т.п. культурно-просветительной работы «среди пролетарских и широких народных масс». Командированные организациями и учреждениями для обучения студенты имели право на стипендию 1800 рублей ежемесячно, а также право на пользование столовой и общежитием ${ }^{10}$.

К 1920 году административно-технический персонал Института состоял из 11 человек, педагогический - из 24 преподавателей. Институт располагался в двух зданиях, принадлежавших ранее вдове купца С.В. Поповой, и доме Андреева, располо- 
женных на улице Кривцовской (ныне Пионерская $)^{11}$.

Учебный план института предусматривал как теоретические, так и практические занятия. К общим курсам относились история и теория научного социализма, Конституция РСФСР, Положение о единой трудовой школе, психология, педагогика, школьная гигиена, основы физического и эстетического воспитания, иностранный язык. Естественно, изучались и специальные предметы по профилю отделений. Студентам читались лекции, проводились семинарские, практические и лабораторные занятия.

Важно отметить, что в годы своего становления Институт народного образования был достаточно свободен в формировании комплекта читаемых для студентов дисциплин. Конечно, соблюдался принцип ориентации на рекомендуемые наркоматом дисциплины, однако при этом серьезно учитывалась специфика местного кадрового состава, возможности оренбургских преподавателей. Это хорошо видно по набору и названиям предметов.

Так, на основном курсе преподавались: Анатомия и физиология человека (В.П. Виноградов), История социализации и история культуры (Н.И. Львов), Школоведение, Методика трудовых процессов, Методика французского языка (А.Ф. Парфянович), Математика (А.К. Торопов, В.Ю. Михневич, Е.Е. Малинин), Политическая экономика (В.А. Еловиков), История научного миросозерцания (Н.А. Лебедев), Немецкий язык (В.Ю. Бемер), Психология (В.Я. Струминский), Педагогическое рисование (Л.М. Красиков), Гигиена (А.К. Навикий), Чтение о праве и государстве в связи с советской концепцией (В.А. Буянов), Латинский язык (К.К. Безин), Физика (А.Ф. Виноградов), Принципы трудовой школы (3.Н. Недина).

На словесно-историческом отделении преподавались: История русского языка (С.М. Барсуков), История античной культуры (В.М. Костров), История русской культуры, История русской литературы первой половины XIX века, История местного края (А.П. Чулошников), Французский язык (А.Ф. Парфянович), Немецкий язык (А.Ю. Бемер), История русской литературы XVIII века (А.В. Бардин), Всеобщая литература (Н.И. Бутовский).

На физико-математическом факультете преподавались: Высшая алгебра (К.А. Миронов), Аналитическая математика (Е.Е. Малинин), Введение в анализ (И.М. Чубинский), Физика (А.Ф. Виноградов), Химия (Е.А. Шатт).

На биологическом факультете преподавались: Зоология (Н.И. Мовчалов), Ботаника (В.И. Коробов), Общее землеведение (В.П. Виноградов), Химия (Е.А. Шатт), Физика (А.Ф. Виноградов), Математика (В.Ю. Михневич, К.А. Торопов).

На отделении трудовых процессов преподавались: Технология (М.И. Витковский), Сельское хозяйство (А.М. Каллистов), Столярное ремесло (М.В. Васильев), Слесарное ремесло (М.Я. Белов, П.Е. Шакин).

Также в Институте отдельно преподавались такие дисциплины эстетического цикла, как Музыка (И.В. Кусков) и Пение (И.И. Третьяков) ${ }^{12}$.

Серьезное внимание уделялось в Институте практической подготовке: было создано несколько лабораторий (химическая, биологическая) и кабинетов (физический, исторический), рисовальный класс и столярная мастерская; для организации педагогической практики Институту были приданы детский сад, школы первой и второй ступеней, а также опытное поле. Разработка проекта организации показательной школы при институте началась 8 апреля 1920 года. Разработка проекта школы 2-й ступени началась 21 апреля того же года ${ }^{13}$.

Чтобы открыть доступ в институт народного образования детям рабочих и крестьян, с 1 января 1920 года при нем открылось подготовительное отделение для лиц, получивших незаконченное среднее образование, «но имеющих влечение к просветительной работе». Для данных студентов целевым образом были выделены места в 
общежитии и стипендии ${ }^{14}$. В рамках подготовительного отделения преподавались: Русский язык и литература (К.К. Безин), Алгебра (К.А. Торопов), Геометрия (В.Е. Малинов), Физика (А.Ф. Виноградов), Естествоведение (В.П. Виноградов), Рисование (Л.М. Красиков), Немецкий язык (А.Ю. Бемер), Французский язык (А.Ф. Парфянович), Трудовые процессы (М.И. Витковский) ${ }^{15}$.

Переход к системному образовательному процессу и расширение количества структурных подразделений вызвали проблему нехватки площадей. Она была оперативно решена. Постановлением Коллегии орготдела губотнаробраза от 2 января 1920 г. здание бывших Духовной семинарии и Епархиального училища было передано Институту народного образования. Причем из документов видно, что на это здание также претендовал Политпросвет Оренбургукрепрайона, однако решение было вынесено в пользу Института. С 15 апреля в данном здании также начались занятия ${ }^{16}$.

Местные органы советской власти оказывали Оренбургскому институту народного образования необходимую помощь не только в выделении помещений, но и в их ремонте, оборудовании учебных аудиторий и общежития. 4 марта 1920 года Оренбургскому институту народного образования даже был предоставлен питомник в поселке Мазуровском, а 22 ноября там же для Института был арендован участок земли с целью практической подготовки учителей по биологическим дисциплинам ${ }^{17}$. Институт в свою очередь оперативно использовал открывающиеся возможности. Так, уже с 25 апреля студенты приступили к работе в питомнике, группами по 20-30 человек, каждая в течение недели ${ }^{18}$.

Что же касается пополнения библиотеки Института необходимой современной научной, учебной, политической и художественной литературой, а также наглядными материалами, то в связи с отсутствием в губернии необходимых учебных материалов ректор В.Я. Струминский в июне 1920 года отправился в Москву и привез оттуда учебных пособий, приборов для кабинетов и книг на сумму 1,1 млн рублей ${ }^{19}$.

Интересна логика подготовки будущих учителей. Воспроизведем ее на примере трехлетней подготовки школьных преподавателей «социально-исторического цикла».

Первый курс:

Осенний семестр: Политическая экономия, Советская конституция, История культуры, Общая психология, Анатомия и физиология, Устная словесность, История всеобщей литературы, История Русской культуры.

Весенний семестр: Политическая экономия, Общая психология, Анатомия и физиология, История Русского языка, История всеобщей литературы, История русской литературы до 19 века, История Русской культуры.

Второй курс:

Осенний семестр: История научного миросозерцания, История и теория научного социализма, Педагогика и история педагогики, История литературы первой половины 19 века, История всеобщей литературы, История древнего Востока, История русской культуры, Политическая экономия в связи с историческим хозяйством быта, История античной культуры.

Весенний семестр: История научного миросозерцания, Педагогика и история педагогики, История литературы второй половины 19 века, История литературы 20 века, История античной культуры, История русской культуры, История новой культуры, Социология, Политическая экономия в связи с хозяйством быта.

Третий курс:

Осенний семестр: Психология и психопатология детей школьного возраста, Школьное самоуправление и школьное хозяйство, Физическое и эстетическое воспитание, История поэтики, История новой культуры, Методика истории культуры, Методика обществоведения, История литературы 20 века.

Весенний семестр: Психология и психопатология детей школьного возраста, Физи- 
ческое и эстетическое воспитание, История 19 века, История местного края, Методика истории культуры, Методика философской пропедевтики ${ }^{20}$.

В рамках данных дисциплин преобладали занятия, ориентированные на практическое применение знаний и умений в педагогической деятельности.

Осенью 1920 года решением Оренбургского губисполкома педагогические учебные заведения города, в том числе и Институт народного образования, были включены в группу ударных. Важность их работы подчеркивалась даже тем фактом, что преподаватели и студенты стали обеспечиваться тыловым красноармейским пайком ${ }^{21}$.

При этом работа студентов и преподавателей Института не ограничивалась только лишь учебным процессом. Студенты института вели достаточно большую работу среди населения. Они участвовали в ликвидации неграмотности, в переписи населения, в первых коммунистических субботниках, боролись с беспризорностью среди детей. Общественной деятельностью занимались, естественно, и преподаватели. Так, например, газета «Коммунар» в номере от 18 февраля 1921 года сообщала, что 20 февраля в помещении института состоится заседание школьной секции научно-педагогического общества, где будет заслушан доклад Н.А. Лебедева «Новая социальная жизнь и единая трудовая школа». На этом заседании выступил и В.Я. Струминский ${ }^{22}$.

Струминский и Лебедев явились инициаторами создания секции психологии при существовавшем в городе научно-педагогическом обществе. Так, 4 апреля председатель секции Лебедев сделал сообщение на тему «Как возникает семья», а Струминский на одном из последующих заседаний рассказал об актуальных проблемах психологии. В июне 1921 года на съезде работников социального воспитания он выступил с докладом о моральном воспитании.

На 1921 год в Оренбургском институте народного образования действовали отделы: школьный, дошкольный и внешколь- ный, а также подготовительное отделение. Места для вновь поступающих, общим количеством двести, были распределены следующим образом: школьный отдел - 75, дошкольный - 25 , внешкольный - 25 , подготовительное отделение - 75. Вступительные испытания для первых трех отделов были определены как экзамены по алгебре, геометрии, русскому языку и физике, а для подготовительного - арифметика и алгебра, геометрия, русский язык ${ }^{23}$. С таким багажом Институт подошел к новому этапу своего развития, связанному с реакцией на новаторскую советскую национальную политику и на форс-мажорную ситуацию крупного голода.

Летом 1921 года Поволжье, Оренбургскую губернию и другие районы страны охватила засуха. В городах и селах ощущалась острая нехватка продовольствия. Газета «Степная правда» сообщала, что, по данным на 1 февраля 1922 года, в Оренбургской губернии голодало 560 тысяч человек, в том числе 209 тысяч детей. Голод, охвативший Оренбуржье, серьезно осложнил положение учебных заведений. Многие школы, особенно на селе, просто прекратили свое существование. Тяжелая участь не миновала и Институт. Некоторые сотрудники вуза были вынуждены уехать из города. Оставшиеся преподаватели и студенты испытывали острую нужду в продовольствии. Из-за голода учебные заведения города, в том числе и Институт, с 1 апреля 1922 года были распущены на каникулы. Эти трагические социально-экономические процессы сопровождались в губернии также и серьезной организационной реорганизацией, вызванной созданием в составе РСФСР Киргизской автономной ССР и наделением города Оренбурга статусом республиканского центра ${ }^{24}$. Данный процесс неоднозначно повлиял на развитие Оренбургского института народного образования, который был поставлен перед сложной задачей учета национальной специфики названной республики. Это был совершенно особый этап в развитии Института, выходящий за рам- 
ки его становления, которое завершилось к 1921 году.

\section{ПРИМЕЧАНИЯ}

1 Любичанковский С.В. Политика аккультурации средствами просвещения исламских подданных Российской империи: исторический опыт Оренбургского края (середина XIX - начало XX вв.). Оренбург, 2018. 264 с.; Любичанковский С.B. Образовательная политика Российской империи и формирование казахской интеллигенции на территории Оренбургского края во второй половине XIX века // Самарский научный вестник. 2018. Т. 7. № 4. С. 245-249.

${ }^{2} \mathrm{O}$ значимости оренбургской учительской семинарии подробнее см.: Любичанковский C.B. Выдающиеся педагоги Оренбургской учительской семинарии // Вестник Оренбургского государственного педагогического университета. Электронный научный журнал. 2018. № 3 (27). С. 121-129.

3 Летопись Оренбургского государственного педагогического университета (1919-2019) / Глав. ред. С.А. Алешина; сост. С.В. Любичанковский. Оренбург: Издательский центр ОГАУ, 2019. С.5.

${ }^{4}$ Государственный архив Оренбургской области (далее - ГАОО). Ф. 1775. Оп. 1. Д. 16. Л. 15.

${ }^{5}$ ГАОО. Ф. 1775. ОП. 1. Д. 16. Л. 18.

${ }^{6}$ ГАОО. Ф. 1775. ОП. 1. Д. 25. Л. 3.

${ }^{7}$ ГАОО. Ф. 1775. ОП. 1. Д. 50. Л. 75.

${ }^{8}$ ГАОО, Ф. 1775, ОП. 1. Д. 26, Л. 32.

${ }^{9}$ ГАОО. Ф. 1775. ОП. 1. Д. 26. Л. 60.

${ }^{10}$ ГАОО. Ф. 1775. ОП. 1. Д. 16. Л. 27.

${ }^{11}$ Историко-архивная справка об открытии Оренбургского Госпединститута. Сост. И.Е. Хотеенков. Под. ред. В.С. Болодурина, Н.А. Шехтмана. Оренбург, 1996. 16 с.

${ }^{12}$ ГАОО. Ф. 1775. ОП. 1. Д. 25. Л. 4.

${ }^{13}$ ГАОО. Ф. 1775. ОП. 1. Д. 47. Л. 2.

${ }^{14}$ ГАОО. Ф. 1775. ОП. 1. Д. 52. Л. 20.

${ }^{15}$ ГАОО. Ф. 1775. ОП. 1. Д. 52. Л. 3.

${ }^{16}$ ГАОО. Ф. 1775. ОП. 1. Д. 53. Л. 22.

${ }^{17}$ ГАОО. Ф. 1775. ОП. 1. Д.32. Л. 104.

${ }^{18}$ ГАОО. Ф. 1775. ОП. 1. Д.50. Л. 34.

${ }^{19}$ ГАОО. Ф. 1775. ОП. 1. Д.50. Л. 83.

${ }^{20}$ ГАОО. Ф. 1775. Оп. 1. Д.50. Л. 5.

${ }^{21}$ ГАОО. Ф. 1775. ОП. 1. Д.56.

${ }^{22}$ Коммунар. 1921. 20 февраля.

${ }^{23}$ ГАОО. Ф. 1775. Оп. 1. Д.50. Л. 28.

${ }^{24}$ Lyubichankovskiy S., Akanov K. Orenburg in the History of Integration of Kazakh Steppe in the Russian Imperia XVIII - beginning of XX century // Bylye Gody. 2018. Vol. 48. Is. 2. P. 491-495.

\title{
ORGANIZATION AND FORMATION OF THE ORENBURG INSTITUTE OF PUBLIC EDUCATION IN 1919-1921
}

\author{
(C) 2020 S.V. Lyubichankovskiy
}

\author{
Samara Federal Research Scientific Center RAS \\ Orenburg State Pedagogical University, Orenburg
}

\begin{abstract}
On the basis of archival documents extracted from the funds of the State Archives of the Orenburg Region, the article reconstructs the process of organizing a new higher educational institution of pedagogical profile in Orenburg - the Institute of Public Education. The first stage of its development (1919-1921), associated with the formation of this educational institution, the creation of its material base, the formation of the staff and the structure of the educational process, is considered.

Keywords: education, Institute of Public Education, pedagogical universities, Soviet Russia, Orenburg region.
\end{abstract}

DOI: $10.37313 / 2658-4816-2020-2-4-29-35$

\footnotetext{
Sergey Lyubichankovsky, Doctor of History, Professor, Leading Researcher at the Samara Federal Research Center of the Russian Academy of Sciences, Head of the Department of History of Russia at Orenburg State Pedagogical University.E-mail: svlubich@yandex.ru
} 